ARTICLE

Received 20 Apr 2015 | Accepted 27 Nov 2015 | Published 7 Jan 2016

DOI: $10.1038 /$ ncomms10317

OPEN

\title{
Molar tooth carbonates and benthic methane fluxes in Proterozoic oceans
}

\author{
Bing Shen ${ }^{1,2, \star}$, Lin Dong ${ }^{1, \star}$, Shuhai Xiao ${ }^{3}$, Xianguo Lang ${ }^{1,2}$, Kangjun Huang $^{1,2}$, Yongbo Peng ${ }^{4}$, Chuanming Zhou ${ }^{5}$,
} Shan $\mathrm{Ke}^{6} \&$ Pengju Liu ${ }^{7}$

Molar tooth structures are ptygmatically folded and microspar-filled structures common in early- and mid-Proterozoic ( $\sim 2,500-750$ million years ago, Ma) subtidal successions, but extremely rare in rocks $<750 \mathrm{Ma}$. Here, on the basis of $\mathrm{Mg}$ and $\mathrm{S}$ isotopes, we show that molar tooth structures may have formed within sediments where microbial sulphate reduction and methanogenesis converged. The convergence was driven by the abundant production of methyl sulphides (dimethyl sulphide and methanethiol) in euxinic or $\mathrm{H}_{2} \mathrm{~S}$-rich seawaters that were widespread in Proterozoic continental margins. In this convergence zone, methyl sulphides served as a non-competitive substrate supporting methane generation and methanethiol inhibited anaerobic oxidation of methane, resulting in the buildup of $\mathrm{CH}_{4}$ formation of degassing cracks in sediments and an increase in the benthic methane flux from sediments. Precipitation of crack-filling microspar was driven by methanogenesis-related alkalinity accumulation. Deep ocean ventilation and oxygenation around $750 \mathrm{Ma}$ brought molar tooth structures to an end.

\footnotetext{
${ }^{1}$ Key Laboratory of Orogenic Belts and Crustal Evolution, MOE, Beijing 100871, China. ${ }^{2}$ School of Earth and Space Sciences, Peking University, No.5 Yiheyuan Road Haidian District, Beijing 100871, China. ${ }^{3}$ Department of Geosciences, Virginia Tech, Blacksburg, Virginia 24061, USA. ${ }^{4}$ Department of Geology and Geophysics, Louisiana State University, Baton Rouge, Louisiana 70803, USA. ${ }^{5}$ Key Laboratory of Economic Stratigraphy and Palaeogeography, Nanjing Institute of Geology and Palaeontology, Chinese Academy of Sciences, Nanjing 210008, China. ${ }^{6}$ State Key Laboratory of Geological Processes and Mineral Resources, China University of Geosciences, Beijing 100083, China. ${ }^{7}$ Institute of Geology, Chinese Academy of Geological Sciences, Beijing 100037 , China.

* These authors contributed equally to this work. Correspondence and requests for materials should be addressed to B.S. (email: bingshen@pku.edu.cn).
} 
M olar tooth carbonates (MTCs), or carbonate rocks containing molar tooth structures (MTSs), occur mostly if not exclusively in successions deposited in subtidal environments before $750 \mathrm{Ma}$ (refs 1,2). The formation of MTCs requires the generation of cracks within unconsolidated sediments, followed by the rapid infilling of such cracks with early diagenetic calcispar before sediment compaction. The formation of molar tooth (MT) cracks have been variously related to subaqueous syneresis ${ }^{3}$, gas bubble expansion resulting from $\mathrm{CH}_{4}, \mathrm{H}_{2} \mathrm{~S}$ or $\mathrm{CO}_{2}$ degassing ${ }^{2,4-6}$ and seismic activities ${ }^{7,8}$. The disappearance of MTCs at around $750 \mathrm{Ma}$ has been related to the rise of animals ${ }^{5,7-9}$, a drop in calcite saturation of seawater ${ }^{1,2,10}$ or an increase in the concentrations of calcite precipitation inhibitors such as $\mathrm{Fe}^{2+}, \mathrm{Mg}^{2+}, \mathrm{SO}_{4}^{2-}$ or $\mathrm{PO}_{4}$ (refs $1-3,11$ ).

To illuminate the origin of MTCs, we measured the Mg, S and C isotopic compositions of MTCs from the early Neoproterozoic (1,000-750 Ma) Wanlong Formation in southern Jilin Province of North China (Supplementary Fig. 1). In the Wanlong Formation, MTSs are abundant within the thick-bedded argillaceous lime mudstone that is intercalated with the finely laminated limestone (Supplementary Note 1 and Supplementary Figs 2 and 3a). Sedimentological evidence, including the predominance of parallel bedding and the lack of subaerial exposure structures, indicates that MTCs in the Wanlong Formation was deposited below fair-weather wave base ${ }^{12}$. S isotopic data indicate that MT microspar was precipitated within microbial sulphate reduction (MSR) zone and $\mathrm{Mg}$ isotopic data suggest that microspar precipitation predated the dolomitization of host rock. We propose that MT microspar was precipitated in the sediment column where MSR and methanogenesis occur simultaneously underneath sulphidic seawaters and where the production of $\mathrm{CH}_{4}$ from methyl sulphides and the inhibition of $\mathrm{CH}_{4}$ oxidation by methanethiol allowed $\mathrm{CH}_{4}$ to build up in the sediments.

\section{Results}

Petrographic observations of the MTCs. MTSs are normally oriented vertically or obliquely with respect to bedding planes and show clear cross-cutting relationships with each other (Supplementary Fig. 3b-d). MT cracks are filled with microcrystalline calcite crystals (MT microspars) ranging from 10 to $20 \mu \mathrm{m}$ in size (Supplementary Fig. 3e,f). The argillaceous host rocks (with an average siliciclastic content of $33.4 \mathrm{wt} \%$, Supplementary Table 5) are partially dolomitized (Supplementary Fig. 3g,h)

Isotopic compositions of the MTCs. Sulphur isotopic values of carbonate-associated sulphate (CAS) extracted from MT microspars $\left(\delta^{34} \mathrm{~S}_{\mathrm{MT}}: 31.9-42.8 \%\right)$ are higher than those of CAS from calcareous host rock $\left(\delta^{34} \mathrm{~S}_{\mathrm{HR}}\right.$ : 19.1-27.6\%; Fig. 1a,
Supplementary Fig. 4 and Supplementary Table 2). Mg isotopic compositions of MT microspars $\left(\delta^{26} \mathrm{Mg}_{\mathrm{MT}}\right)$ is around $-3.3 \%$ (relative to DSM3), $\sim 1.6 \%$ lower than those of the host rock $\left(\delta^{26} \mathrm{Mg}_{\mathrm{HR}}\right.$; Fig. 1b, Supplementary Fig. 5 and Supplementary Table 1$)$. C isotopes of MT microspars $\left(\delta^{13} \mathrm{C}_{\mathrm{MT}}\right)$ are systematically heavier than host rock $\left(\delta^{13} \mathrm{C}_{\mathrm{HR}}\right)$ by $0.5-1 \%$ (Fig. $1 \mathrm{c}$ and Supplementary Table 3).

\section{Discussion}

$\delta^{34} \mathrm{~S}_{\mathrm{HR}}$ of the Wanlong carbonates is within the range of sulphur isotopic compositions of Neoproterozoic $\mathrm{CAS}^{13}$. The greater values of $\delta^{34} \mathrm{~S}_{\mathrm{MT}}$ indicate that MT microspar was precipitated in the sulphate reduction zone in the sediment column, where ${ }^{32} \mathrm{~S}$ is preferentially removed from the porewater sulphate pool by sulphate reduction microbes ${ }^{14}$ (Supplementary Note 2). MT microspar precipitation in the MSR zone is also consistent with generally lower CAS concentrations in MT microspar than in host rock (Supplementary Fig. 6 and Supplementary Table 4).

$\delta^{26} \mathrm{Mg}_{\mathrm{MT}}$ is related to the $\mathrm{Mg}$ isotopic composition of porewater $\left(\delta^{26} \mathrm{Mg}_{\mathrm{pw}}\right)$, from which MT microspar precipitates, and the relationship can be expressed as follows:

$$
\delta^{26} \mathrm{Mg}_{\mathrm{pw}}=\delta^{26} \mathrm{Mg}_{\mathrm{MT}}+\Delta_{\mathrm{cal}}
$$

where $\Delta_{\text {cal }}$ is the fractionation associated with inorganic precipitation of low- $\mathrm{Mg}$ calcite and can be set at $2.2-2.7 \%$ (refs 15,16). Thus, $\delta^{26} \mathrm{Mg}_{\mathrm{pw}}$ is estimated to be between -0.6 and $-1.1 \%$, within the range of seawater compositions in the past 70 million years ${ }^{17,18}$. Greater $\delta^{26} \mathrm{Mg}_{\mathrm{HR}}$ values might be attributed to the partial dolomitization of host rock, because dolostone is systematically heavier than limestone in $\mathrm{Mg}$ isotopes ${ }^{19,20}$. On the other hand, as dolomite and other authigenic $\mathrm{Ca}$ carbonate formed in the sediment column would preferentially scavenge ${ }^{24} \mathrm{Mg}$ from porewater ${ }^{21,22}$ (Supplementary Note 3 ), $\delta^{26} \mathrm{Mg}_{\mathrm{pw}}$ would increase as dolomitization proceeds. It is estimated that $10-25 \mathrm{wt} \%$ of carbonate in the host rock of the Wanlong Formation is dolomitized (Fig. 1b), meaning $\delta^{26} \mathrm{Mg}_{\mathrm{pw}}$ would increase by $\sim 2 \%$ (Supplementary Fig. 7). Had MT microspar in the Wanlong Formation precipitated after host rock dolomitization, seawater $\mathrm{Mg}$ isotopic composition would have to be between -2.6 and $-3.1 \%$, which is even lower than the influx from carbonate weathering $(-2.25 \%$; that is, the lower bound of riverine input $)^{18}$. Thus, MT microspar precipitation must predate host rock dolomitization. This inference is also consistent with the petrographic observation that MT structures are often ptygmatically folded and sometimes brittly fractured ${ }^{1}$, suggesting that MT microspar was precipitated before host rock cementation. In this light, it is possible that the exclusive occurrence of MT structures in argillaceous carbonates ${ }^{1}$ may be related to clay minerals, which tend to delay host rock cementation $^{23}$.
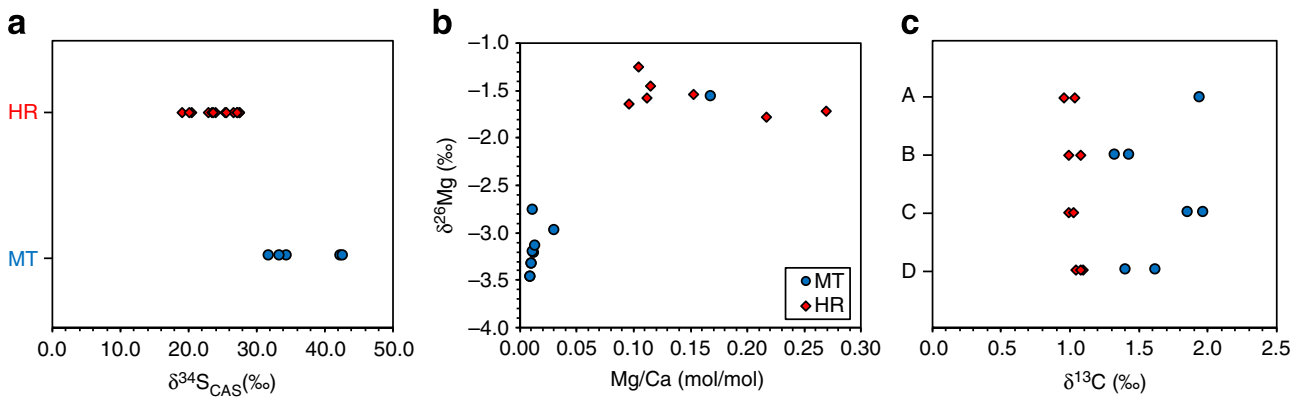

Figure 1 | Isotopic compositions of MTCs. (a) S isotopic compositions of CAS from MT calcispars (MT) and host rocks (HR). (b) Cross-plot of $\mathrm{Mg} / \mathrm{Ca}$ (molar ratio) versus $\delta^{26} \mathrm{Mg}$. The argillaceous host rock has higher $\mathrm{Mg} / \mathrm{Ca}$ ratios and is enriched in ${ }^{26} \mathrm{Mg}$ than $\mathrm{MT}$ calcispars. (c) $\mathrm{C}$ isotopic compositions of MT calcispars (MT) versus host rock (HR) of four samples ( $A, B, C$ and D). 

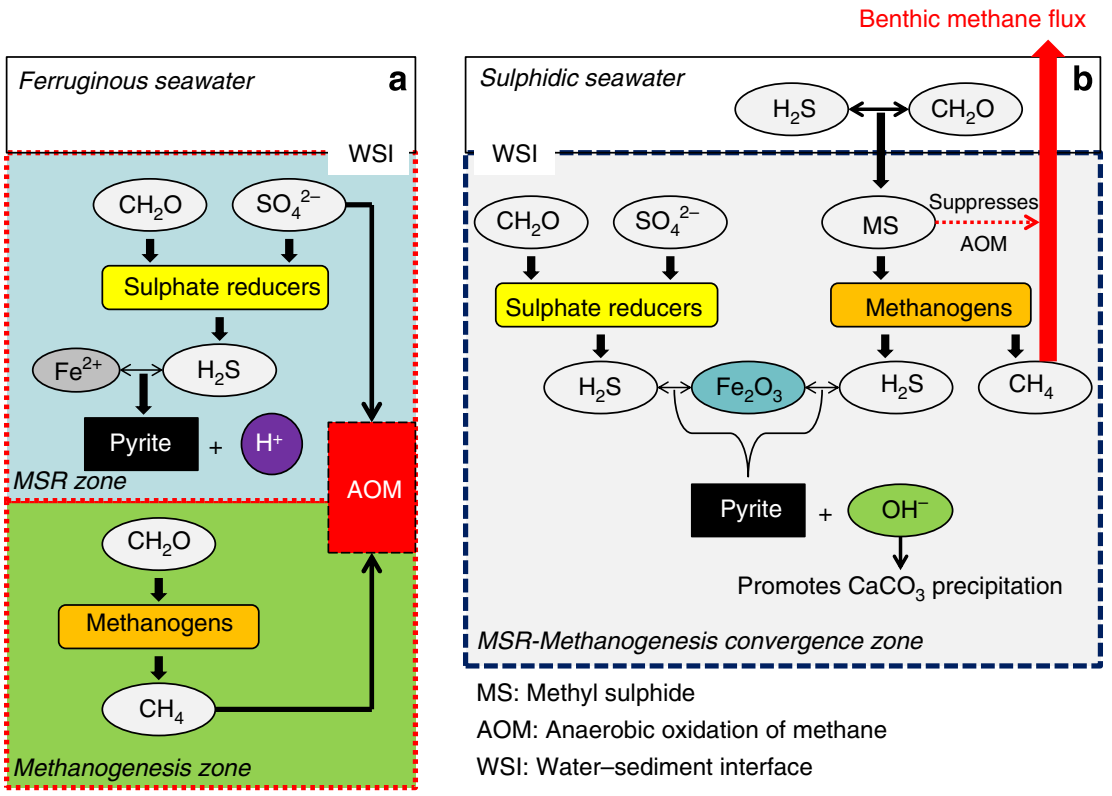

Figure 2 | Schematic diagram showing geochemical reactions within marine sediments bathed beneath ferruginous and sulphidic seawaters.

(a) Under ferruginous conditions, the MSR and methanogenesis zones are separated. Methanogens are outcompeted by sulphate-reducing bacteria, if both use competitive substrates $\left(\mathrm{CH}_{2} \mathrm{O}\right)_{n}$. Within the MSR zone, reaction between $\mathrm{H}_{2} \mathrm{~S}$ and $\mathrm{Fe}^{2+}$ precipitates pyrite and generates $\mathrm{H}^{+}$, which lowers porewater $\mathrm{pH}$. Most $\mathrm{CH}_{4}$ produced within methanogenesis zone is oxidized by sulphate at the base of MSR zone where AOM occurs. Thus, there is little benthic $\mathrm{CH}_{4}$ flux from marine sediments. (b) Under sulphidic conditions, methyl sulphides are produced within both water column and sediments. In sediments, methyl sulphides serve as a non-competitive substrate for methanogens, allowing MSR and methanogenesis to take place concurrently in the MSR-methanogenesis convergence zone. $\mathrm{H}_{2} \mathrm{~S}$ and $\mathrm{Fe}_{2} \mathrm{O}_{3}$ react to produce pyrite and generate $\mathrm{OH}^{-}$, thus favouring $\mathrm{CaCO}_{3}$ precipitation. $\mathrm{AOM}$ is prohibited by methanethiol, allowing $\mathrm{CH}_{4}$ accumulation in sediments and significant benthic $\mathrm{CH}_{4}$ fluxes into atmosphere.

Thus, sedimentary evidence, $\mathrm{S}$ isotopes and $\mathrm{Mg}$ isotopes indicate that MT microspar precipitation must occur in unconsolidated sediments, within the MSR zone and before dolomitization. To generate MT structures, cracks must develop in unlithified sediments and gas expansion is a plausible mechanism to generate such cracks $^{2,4}$. Here we explore the nature of the gases and the unique Proterozoic environments conducive for gas bubble formation in sediments.

During the early to middle Proterozoic, atmospheric oxygen level was extremely low ( $<1 \%$ present atmospheric level) and the deep ocean remained anoxic and sulphidic in place $^{24-27}$. Sulphidic conditions were particularly common in Proterozoic continental margins $25,26,28$ and perhaps in epicratonal environments as well ${ }^{29,30}$. Although euxinia may have extended over $<10 \%$ of global seafloor in mid-Proterozoic according to some estimates ${ }^{27}$, sulphidic waters might have had profound impacts on the Proterozoic Earth system. We propose that methyl sulphides might have been produced in significant quantities in sulphidic marine environments. Methyl sulphides are a group of volatile organic sulphur compounds, including dimethyl sulphide $\left(\mathrm{CH}_{3} \mathrm{SCH}_{3}\right)$ and methanethiol $\left(\mathrm{CH}_{3} \mathrm{SH}\right)$, which are produced in modern marine and freshwater environments. Methyl sulphides can be produced either by the degradation of dimethylsulphoniopropionate in the surface ocean ${ }^{31}$ or by anaerobic methylation of hydrogen sulphide in sulphidic sediments $^{32}$. Therefore, it is expected that the production of methyl sulphides would be enhanced in Proterozoic sulphidic marine environments, both in the water column and within sediments.

As volatile gases, methyl sulphides produced in water column tend to readily emit to atmosphere, but those generated within the sediments can serve as a non-competitive substrate for methanogens ${ }^{33-35}$. As sulphur-reducing microbes cannot use methyl sulphides but methanogens can, MSR and methanogenesis can co-occur simultaneously within sediments where methyl sulphides are present ${ }^{36}$, resulting in the convergence of the MSR and methanogenesis zones. In addition, anaerobic oxidation of methane (AOM) is inhibited by methyl sulphides such as methanethiol. With methane oxidation inhibited, $\mathrm{CH}_{4}$ can accumulate in sediments in significant quantity ${ }^{37}$, in sharp contrast to modern marine sediments, where the MSR zone lies invariably above the methanogenesis zone $^{38}$, with intensive AOM at the base of MSR zone consuming most $\mathrm{CH}_{4}$ and consequently modern marine $\mathrm{CH}_{4}$ discharge accounting for only $2 \%$ of the global flux ${ }^{39}$ (Fig. 2).

We propose that the accumulation of the insoluble gas $\mathrm{CH}_{4}$ in the convergence zone provided a physical mechanism to generate cracks in unconsolidated sediments ${ }^{2,4}$. Furthermore, the geochemistry within the convergence zone where MSR and methanogenesis overlap could have facilitated the precipitation of calcite to fill such cracks. With the generally low concentrations of $\mathrm{Fe}^{2+}$ in sulphidic porewaters, pyrite formation would involve the reaction between $\mathrm{H}_{2} \mathrm{~S}$ and $\mathrm{Fe}_{2} \mathrm{O}_{3}$. In fact, the host rock of MTCs in the Wanlong Formation contains an average of $0.42 \mathrm{wt} \%$ of pyrites (Supplementary Table 5). The overall reactions for pyrite formation fueled by MSR and methanogenesis using methanethiol and dimethyl sulphide can be described as follows:

$4 \mathrm{CH}_{2} \mathrm{O}+2 \mathrm{SO}_{4}^{2-}+\mathrm{Fe}_{2} \mathrm{O}_{3}=\mathrm{FeS}_{2}+\mathrm{Fe}^{2+}+4 \mathrm{HCO}_{3}^{-}+2 \mathrm{OH}^{-}+\mathrm{H}_{2} \mathrm{O}$

$4 \mathrm{CH}_{3} \mathrm{SH}+2 \mathrm{Fe}_{2} \mathrm{O}_{3}=3 \mathrm{CH}_{4}+2 \mathrm{FeS}_{2}+2 \mathrm{Fe}^{2+}+\mathrm{HCO}_{3}^{-}+3 \mathrm{OH}^{-}$

$2 \mathrm{CH}_{3} \mathrm{SCH}_{3}+\mathrm{Fe}_{2} \mathrm{O}_{3}+\mathrm{H}_{2} \mathrm{O}=3 \mathrm{CH}_{4}+\mathrm{FeS}_{2}+\mathrm{Fe}^{2+}+\mathrm{HCO}_{3}^{-}+\mathrm{OH}^{-}$ 
These reactions generate $\mathrm{OH}^{-}$and $\mathrm{HCO}_{3}^{-}$, which elevate $\mathrm{pH}$, increase porewater alkalinity and favour $\mathrm{CaCO}_{3}$ precipitation ${ }^{40-42}$. In addition, the dearth of calcite inhibitors such as $\mathrm{Fe}^{2+}$ and $\mathrm{SO}_{4}^{2-}$ in sulphidic sediments would also promote rapid precipitation of $\mathrm{CaCO}_{3}$ (ref. 11).

$\delta^{13} \mathrm{C}_{\mathrm{MT}}$ of the Wanlong carbonate is only slightly greater than $\delta^{13} \mathrm{C}_{\mathrm{HR}}$ by $0.5-1 \%$ (Fig. 1c), similar to previous studies showing that MT microspar and host carbonate rock have nearly indistinguishable $\delta^{13} \mathrm{C}$ values ${ }^{5,6,43}$. To assess the extent of carbon isotope variation between MT microspar and host rock, we consider a simple model where methanogenesis produces sufficient $\mathrm{CH}_{4}$ to produce cracks that are immediately filled with MT microspar. To generate cracks by $\mathrm{CH}_{4}$ accumulation, gas pressure must be balanced with the hydrostatic pressure, which is dependent on water depth. Our calculation shows that methanogenesis alone does not generate sufficient bicarbonate (and MT microspar) to fill the cracks that would be created at reasonable water depths by the amount of $\mathrm{CH}_{4}$ it produces. Thus, MT microspar precipitation was probably supplemented by porewater bicarbonate (which would be isotopically similar to seawater bicarbonate and to $\delta^{13} C_{\text {host }}$ ) and bicarbonate derived from sulphate reduction (Supplementary Note 4). To simplify our calculation, we consider the simplest situation in which bicarbonate derived from methanogenesis was entirely used in MT microspar precipitation, with additionally needed alkalinity coming from porewater (that is, a binary mixing model). Assuming that $\delta^{13} \mathrm{C}$ of methyl sulphides and carbon isotope fractionation during methanogenesis are $-30 \%$ and $-60 \%$

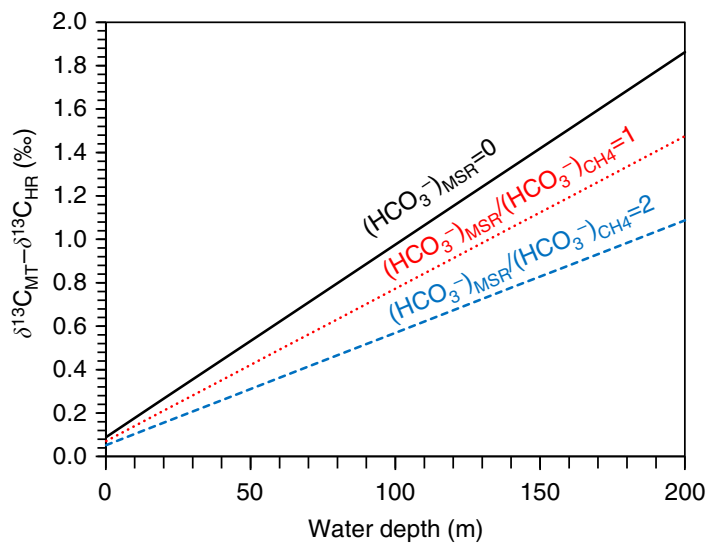

Figure 3 | Geochemical model showing the carbon isotopic difference between MT microspar and host rock formed at different water depths. First, the amount of $\mathrm{CH}_{4}$ required to produce a unit volume of cracks at ambient pressure and temperature was estimated. The co-production of $\mathrm{HCO}_{3}^{-}$related to $\mathrm{CH}_{4}$ generation was then estimated and assumed to have been used fully for MT microspar precipitation. The methanogenic $\mathrm{HCO}_{3}^{-}$ was inadequate to precipitate enough MT microspar to fill a unit volume and the shortage was made up by (1) pore water $\mathrm{HCO}_{3}^{-}$(black solid line); (2) $\mathrm{HCO}_{3}^{-}$from MSR $\left(\left(\mathrm{HCO}_{3}^{-}\right)_{\mathrm{MSR}}\right)$ and methanogenesis $\left(\left(\mathrm{HCO}_{3}^{-}\right)_{\mathrm{CH} 4}\right)$ with a molar ratio of 1:1, and the remaining shortage fulfilled by pore water $\mathrm{HCO}_{3}^{-}$(red dotted line); or (3) $\mathrm{HCO}_{3}^{-}$from MSR and methanogenesis with a molar ratio of 2:1, and the remaining shortage fulfilled by pore water $\mathrm{HCO}_{3}^{-}$(blue dashed line). Porewater $\mathrm{HCO}_{3}^{-}$was assumed to have a $\delta^{13} \mathrm{C}$ value similar to that of host rock (that is, $1 \%$ ). The $\delta^{13} \mathrm{C}$ value of methanogenic $\mathrm{HCO}_{3}^{-}$was estimated at $+150 \%$, given a $\delta^{13} \mathrm{C}$ value of methyl sulphides at $-30 \%$, a fractionation between $\mathrm{CH}_{4}$ and methyl sulphides at $-60 \%$ and the production of $3 / 4$ mole of $\mathrm{CH}_{4}$ and $1 / 4$ mole of $\mathrm{HCO}_{3}^{-}$from each mole of methyl sulphides (equations (2) and (3)). The

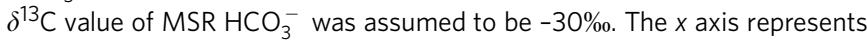
water depths and the $y$ axis indicates the isotopic difference between MT microspar and host rock $\left(\delta^{13} \mathrm{C}_{\mathrm{MT}}-\delta^{13} \mathrm{C}_{\mathrm{HR}}\right)$. (ref. 44), respectively, mass balance consideration requires that $\delta^{13} \mathrm{C}$ of $\mathrm{HCO}_{3}^{-}$derived from methanogenesis be $+150 \%$ based on equations (3) and (4). Our calculation shows that MT microspar precipitation at $100 \mathrm{~m}$ water depth would be $\sim 1 \%$ o heavier than host rock (black solid line in Fig. 3) and methanogenesis-derived $\mathrm{HCO}_{3}^{-}$only accounts for $<1 \%$ of MT microspar precipitation. Smaller isotopic difference between MT microspars and host rock would be expected if MSR-derived $\mathrm{HCO}_{3}^{-}$is involved (dashed lines in Fig. 3).

The disappearance of MTCs is coincident with the elevation of atmospheric oxygen levels at $\sim 750 \mathrm{Ma}$ (refs 1,45 ), suggesting a possible causal relationship. A direct consequence of ocean oxygenation and ventilation is the reduction of the areal coverage of euxinic waters and decrease in methyl sulphide production, which in turn would result in the spatial separation of the MSR and methanogenesis zones in sediments. As such, most $\mathrm{CH}_{4}$ was consumed at the base of MSR zone by AOM, preventing crack formation by $\mathrm{CH}_{4}$ accumulation. Furthermore, pyrite formation in ferruginous sediments through reaction with $\mathrm{Fe}^{2+}$ would generate protons, lowering porewater $\mathrm{pH}$ and favouring $\mathrm{CaCO}_{3}$ dissolution ${ }^{46,47}$. All these secular changes associated with atmospheric and oceanic oxygenation may have contributed to the disappearance of MT structure around $750 \mathrm{Ma}$.

$\mathrm{CH}_{4}$ accumulation in sediments also implies benthic $\mathrm{CH}_{4}$ discharge from marine sediments. The environmental impacts of benthic $\mathrm{CH}_{4}$ fluxes on the Proterozoic Earth system could potentially be profound. First, enhanced $\mathrm{CH}_{4}$ discharge would contribute to the persistently low atmospheric $\mathrm{O}_{2}$ levels in Proterozoic ${ }^{25,48}$. Second, strong benthic $\mathrm{CH}_{4}$ fluxes from continental margins would have contributed to the maintenance of an ice-free Earth in the middle Proterozoic. Finally, a significant reduction of $\mathrm{CH}_{4}$ discharge associated with the $750 \mathrm{Ma}$ oxygenation event might have triggered the Neoproterozoic global glaciations. Thus, the Neoproterozoic oxygenation event may have had an impact on the secular distribution of sedimentary structures such as MT structure and the global climate system, as well as the rise of animals ${ }^{45}$.

\section{Methods}

Mg isotope analysis. Rock samples were split into two parts using a rock saw. A highly polished slab was prepared from one split, while a mirrored thin section was made from the counterpart. Sample powers were drilled from the polished slab using a hand-held micro-drill. The sampling procedure was guided by the petrographic observation of the corresponding thin sections. For $\mathrm{Mg}$ isotopic analysis, about $10-30 \mathrm{mg}$ of powder was dissolved in $0.5 \mathrm{~N}$ acetic acid in a $15-\mathrm{ml}$ centrifuge tube. Tubes were placed in an ultrasonic bath for $30 \mathrm{~min}$, to allow complete dissolution of carbonate components. After centrifuging, supernatant was collected for column chemistry and elemental composition analysis.

$\mathrm{Mg}$ was purified using cation-exchange chromatography. The detailed procedure of column chemistry was reported in Shen, et al. ${ }^{49}$ and Huang et al. ${ }^{20}$ $\mathrm{Mg}$ was purified in two steps. Column 1 was designated to separate $\mathrm{Mg}$ from Ca. $\mathrm{Mg}$ was eluted by $4 \mathrm{ml}$ of $10 \mathrm{~N} \mathrm{HCl}$, whereas Ca was retained in resin. Column 2 was used to separate $\mathrm{Mg}$ from all other elements. $\mathrm{Na}, \mathrm{Al}, \mathrm{Fe}$ and $\mathrm{K}$ were sequentially eluted using $1 \mathrm{~N} \mathrm{HCl}, 1 \mathrm{~N} \mathrm{HNO}_{3}+0.5 \mathrm{~N} \mathrm{HF}$ and $1 \mathrm{~N} \mathrm{HNO}_{3}$, whereas $\mathrm{Mg}$ was collected using $5 \mathrm{ml}$ of $2 \mathrm{~N} \mathrm{HNO}_{3}$. To obtain a pure fraction of $\mathrm{Mg}$, sample solutions passed through column 1 twice, followed by three passes through column 2. After column chemistry, $\mathrm{Ca} / \mathrm{Mg}, \mathrm{Na} / \mathrm{Mg}, \mathrm{Al} / \mathrm{Mg}$ and $\mathrm{Fe} / \mathrm{Mg}$ ratios were $<0.05$ and the $\mathrm{Mg}$ recovery rate was better than $99 \%$.

$\mathrm{Mg}$ isotopic ratios were measured on a Thermo Scientific Neptune Plus high-resolution multicollector inductively coupled plasma mass spectrometry at the Isotope Laboratory in China University of Geosciences, Beijing. The standard-sample bracketing method was used to correct the instrumental mass bias and drift. An in-house solution (FZT) was used as the working standard. Analyses were performed in the low-resolution mode, simultaneously measuring ${ }^{26} \mathrm{Mg}$,

${ }^{25} \mathrm{Mg}$ and ${ }^{24} \mathrm{Mg}$ isotopes. $\mathrm{Mg}$ isotope ratios are reported by the delta notation as \%o deviation relative to the DSM3 standard ${ }^{50}$ :

$$
\delta^{x} \mathrm{Mg}=1000 \times\left[\frac{\left({ }^{x} \mathrm{Mg} /{ }^{24} \mathrm{Mg}\right)_{\text {sample }}}{\left({ }^{x} \mathrm{Mg} /{ }^{24} \mathrm{Mg}\right)_{\text {DSM3 }}}-1\right]
$$

where $x$ refers to 25 or 26 
The internal precision was determined on the basis of $\geq 3$ repeated runs of the same sample solution during a single analytical session and is better than $\pm 0.10 \%$ ( 2 s.d.). The accuracy is determined by the measurements of synthetic solution (GSB-Mg) and USGS basalt standards (BCR-2). Multiple analyses of the synthetic solution (GSB-Mg) yield $\delta^{26} \mathrm{Mg}$ values ranging from -2.07 to $-2.04 \%$, which is consistent with the preferred value of $-2.05 \pm 0.05 \%$ o $(2 \sigma)$. $\delta^{26} \mathrm{Mg}$ of BCR-2 is $-0.17 \pm 0.06 \%$ o $(2 \sigma)$, consistent with the published values ${ }^{51-54}$.

Sulphur isotope analysis. Traditional CAS extraction procedure typically requires $>20 \mathrm{~g}$ of carbonate powder. Thus, it is impossible to collect enough sample powder from MT microspar without contamination from the host rock using the traditional method, because MT cracks are typically a few millimetres in width. To analyse CAS of MT microspar, we devised a new extraction procedure that only requires $\sim 1 \mathrm{~g}$ of carbonate powders for each sample. The validity of the new procedure was verified by analysing the same carbonate sample by using both the traditional and new procedures. Powders were carefully drilled from MT microspar only to a shallow depth so as to avoid the potential contamination from host rock. Often, multiple MT cracks in a polished slab were drilled to collect enough powder for CAS extraction. Sample powder was placed in a 50-ml centrifuge tube and were treated with $10 \% \mathrm{NaCl}$ solution for $24 \mathrm{~h}$ to dissolve non-CAS sulphate. After supernatant removal, residues were washed with deionized water for three times. The above cleaning procedures were repeated at least three times, to ensure complete removal of non-CAS sulphate. The cleaned sample powder was dissolved in $40 \mathrm{ml}$ of $3 \mathrm{~N} \mathrm{HCl}$. After $1 \mathrm{~h}$ of reaction, reaction tubes were centrifuged and the supernatants were collected. About $1-2 \mathrm{mg}$ of nano- $\mathrm{SiO}_{2}$ was added into the centrifuge tube and then $10 \mathrm{ml}$ of saturated $\mathrm{BaCl}_{2}$ was added to precipitate sulphate as barite. The use of nano- $\mathrm{SiO}_{2}$ was to facilitate barite collection. Barite precipitation was allowed to proceed for $48 \mathrm{~h}$. After centrifuging, barite precipitate was washed by DI water for three times, to remove residual $\mathrm{HCl}$, and then dried in an oven.

Sulphur isotopic compositions were measured at Indiana University on a Finnigan Delta V advantage gas source mass spectrometry fitted with a peripheral Costech elemental analyser for on-line sample combustion. Sulphur isotope compositions are reported as \%o deviation from V-CDT, $\delta^{34} \mathrm{~S}=\left(R_{\mathrm{sample}} / R_{\mathrm{V}-\mathrm{CDT}}-1\right) \times 1,000$, where $R$ is the ratio of ${ }^{34} \mathrm{~S} /{ }^{32} \mathrm{~S}$. Analytical error is $\pm 0.1 \%$ o $(1 \sigma)$ as determined from repeated analyses of samples and laboratory standards. The analytical results were calibrated using the standard NBS-127 $\left(20.3 \%\right.$ ) and three internal standards: a silver sulphide (ERE- $\mathrm{Ag}_{2} \mathrm{~S}:-4.3 \%$ ), a chalcopyrite (EMR-CP: $+0.9 \%$ ) and a barite (PQB2: $+40.5 \%$ ).

Inductively coupled plasma optical emission spectrometer analysis. Elemental compositions were determined at Peking University on a Spectro Blue Sop inductively coupled plasma optical emission spectrometer fitted with a Water Cross-flow nebulizer. All analyses were calibrated by a series of gravimetric standards with different concentrations (ranging from 0.1 to 10 p.p.m.) that were run before sample measurements and between every 20 samples. The external reproducibility for the major and minor elements $(\mathrm{Na}, \mathrm{Mg}, \mathrm{Al}, \mathrm{K}, \mathrm{Ca}, \mathrm{Fe}, \mathrm{Mn}$, Sr and S) is $\pm 2 \%$.

\section{References}

1. Shields, G. A. "Molar-tooth microspar": a chemical explanation for its disappearance 750 Ma. Terra Nova 14, 108-113 (2002).

2. Pollock, M. D., Kah, L. C. \& Bartley, J. K. Morphology of molar-tooth structures in Precambrian carbonates: influence of substrate rheology and implications for genesis. J. Sediment. Res. 76, 310-323 (2006).

3. Knoll, A. H. Microbiotas of the late Precambrian Hunnberg Formation, Nordaustlandet, Svalbard. J. Paleontol. 58, 131-162 (1984).

4. Furniss, G., Rittel, J. F. \& Winston, D. Gas bubble and expansion crack origin of "molar-tooth" calcite structures in the middle Proterozoic Belt Supergroup, western Montana. J. Sediment. Res. 68, 104-114 (1998).

5. Frank, T. D. \& Lyons, T. W. "Molar-tooth" structures: a geochemical perspective on a Proterozoic enigma. Geology 26, 683-686 (1998).

6. Marshall, D. \& Anglin, C. D. $\mathrm{CO}_{2}$-clathrate destabilization: a new model of formation for molar tooth structures. Precambrian Res. 129, 325-341 (2004).

7. Fairchild, I. J., Einsel, G. \& Song, T. Possible seismic origin of molar tooth structures in Neoproterozoic carbonate ramp deposits, north China. Sedimentology 44, 611-636 (1997).

8. Pratt, B. R. Molar-tooth structure in Proterozoic carbonate rocks: origin from synsedimentary earthquakes, and implications for the nature and evolution of basins and marine sediment. Geol. Soc. Am. Bull. 110, 1028-1045 (1998).

9. James, N. P., Narbonne, G. M. \& Sherman, A. G. Molar-tooth carbonates: shallow subtidal facies of the mid- to late Proterozoic. J. Sediment. Res. 68, 716-722 (1998).

10. Bartley, J. K. \& Kah, L. C. Marine carbon reservoir, $\mathrm{C}_{\text {org }}-\mathrm{C}_{\text {carb }}$ coupling, and the evolution of the Proterozoic carbon cycle. Geology 32, 129-132 (2004).

11. Sumner, D. Y. \& Grotzinger, J. P. Were kinetics of Archean calcium carbonate precipitation related to oxygen concentration? Geology 24, 119-122 (1996).

12. Kuang, H., Liu, Y., Meng, X. \& GE, M. Molar-tooth structure and sedimentary characteristics of the Wanlong Formation of Neoproterozoic at Erdaojiang section of Tonghua County in southern Jilin Province. J. Palaeogeogr. 8, 457-466 (2006).

13. Canfield, D. E. \& Farquhar, J. Animal evolution, bioturbation, and the sulfate concentration of the oceans. Proc. Natl Acad. Sci. USA 106, 8123-8127 (2009).

14. Habicht, K. S. \& Canfield, D. E. Sulfur isotope fractionation during bacterial sulfate reduction in organic-rich sediments. Geochim. Cosmochim. Acta 61, 5351-5361 (1997).

15. Li, W., Chakraborty, S., Beard, B. L., Romanek, C. S. \& Johnson, C. M. Magnesium isotope fractionation during precipitation of inorganic calcite under laboratory conditions. Earth Planet. Sci. Lett. 333-334, 304-316 (2012).

16. Saulnier, S., Rollion-Bard, C., Vigier, N. \& Chaussidon, M. Mg isotope fractionation during calcite precipitation: an experimental study. Geochim. Cosmochim. Acta 91, 75-91 (2012).

17. Ling, M.-X. et al. Homogenous magnesium isotopic composition of seawater. Rapid Commun. Mass Spectrom. 25, 2828-2836 (2011).

18. Higgins, J. A. \& Schrag, D. P. The Mg isotopic composition of Cenozoic seawater - evidence for a link between $\mathrm{Mg}$-clays, seawater $\mathrm{Mg} / \mathrm{Ca}$, and climate. Earth Planet. Sci. Lett. 416, 73-81 (2015).

19. Azmy, K. et al. Magnesium-isotope and REE compositions of Lower Ordovician carbonates from eastern Laurentia: implications for the origin of dolomites and limestones. Chem. Geol. 356, 64-75 (2013).

20. Huang, K.-J. et al. Magnesium isotopic compositions of the Mesoproterozoic dolostones: implications for $\mathrm{Mg}$ isotopic systematics of marine carbonate. Geochim. Cosmochim. Acta 164, 333-351 (2015).

21. Higgins, J. A. \& Schrag, D. P. Constraining magnesium cycling in marine sediments using magnesium isotopes. Geochim. Cosmochim. Acta 74, 5039-5053 (2010).

22. Li, W., Beard, B. L., Li, C., Xu, H. \& Johnson, C. M. Experimental calibration of $\mathrm{Mg}$ isotope fractionation between dolomite and aqueous solution and its geological implications. Geochim. Cosmochim. Acta 157, 164-181 (2015).

23. Hallam, A. Origin of the limestone-shale rhythm in the Blue Lias of England: a composite theory. J. Geol. 72, 157-169 (1964).

24. Canfield, D. E. A new model for Proterozoic ocean chemistry. Nature 396, 450-453 (1998).

25. Lyons, T. W., Reinhard, C. T. \& Planavsky, N. J. The rise of oxygen in Earth's early ocean and atmosphere. Nature 506, 307-315 (2014).

26. Planavsky, N. J. et al. Widespread iron-rich conditions in the mid-Proterozoic ocean. Nature 477, 448-451 (2011).

27. Reinhard, C. T. et al. Proterozoic ocean redox and biogeochemical stasis. Proc Natl Acad. Sci. USA 110, 5357-5362 (2013).

28. Poulton, S. W., Fralick, P. W. \& Canfield, D. E. Spatial variability in oceanic redox structure 1.8 billion years ago. Nat. Geosci. 3, 486-490 (2010).

29. Gilleaudeau, G. J. \& Kah, L. C. Carbon isotope records in a Mesoproterozoic epicratonic sea: carbon cycling in a low-oxygen world. Precambrian Res. 228, 85-101 (2013).

30. Gilleaudeau, G. J. \& Kah, L. C. Heterogeneous redox conditions and a shallow chemocline in the Mesoproterozoic ocean: evidence from carbon-sulfur-iron relationships. Precambrian Res. 257, 94-108 (2015).

31. Yoch, D. C. Dimethylsulfoniopropionate: its sources, role in the marine food web, and biological degradation to dimethylsulfide. Appl. Environ. Microbiol. 68, 5804-5815 (2002).

32. Lomans, B. P. et al. Formation of dimethyl sulfide and methanethiol in anoxic freshwater sediments. Appl. Environ. Microbiol. 63, 4741-4747 (1997).

33. Kiene, R. P., Oremland, R. S., Catena, A., Miller, L. G. \& Capone, D. G. Metabolism of reduced methylated sulfur compounds in anaerobic sediments and by a pure culture of an estuarine methanogen. Appl. Environ. Microbiol. 52, 1037-1045 (1986).

34. Oremland, R. S., Whiticar, M. J., Strohmaier, F. E. \& Kiene, R. P. Bacterial ethane formation from reduced, ethylated sulfur compounds in anoxic sediments. Geochim. Cosmochim. Acta 52, 1895-1904 (1988).

35. Oremland, R. S. \& Taylor, B. F. Sulfate reduction and methanogenesis in marine sediments. Geochim. Cosmochim. Acta 42, 209-214 (1978).

36. Mitterer, R. M. Methanogenesis and sulfate reduction in marine sediments: a new model. Earth Planet. Sci. Lett. 295, 358-366 (2010).

37. Meulepas, R. J. W., Jagersma, C. G., Khadem, A. F., Stams, A. J. M. \& Lens, P. N. L. Effect of methanogenic substrates on anaerobic oxidation of methane and sulfate reduction by an anaerobic methanotrophic enrichment. Appl. Microb. Cell Physiol. 87, 1499-1506 (2010).

38. Reeburgh, W. S. Oceanic methane biogeochemistry. Chem. Rev. 107, 486-513 (2007).

39. Knittel, K. \& Boetius, A. Anaerobic oxidation of methane: progress with an unknown process. Annu. Rev. Microbiol. 63, 311-334 (2009).

40. Gallagher, K. L., Dupraz, C. \& Visscher, P. T. Two opposing effects of sulfate reduction on carbonate precipitation in normal marine, hypersaline, and alkaline environments: COMMENT. Geology 42, e313-e314 (2014).

41. Meister, P. Two opposing effects of sulfate reduction on carbonate precipitation in normal marine, hypersaline, and alkaline environments. Geology 41, 499-502 (2013). 
42. Visscher, P. T., Reid, R. P. \& Bebout, B. M. Microscale observations of sulfate reduction: Correlation of microbial activity with lithified micritic laminae in modern marine stromatolites. Geology 28, 919-922 (2000).

43. Xiao, S. et al. Biostratigraphic and chemostratigraphic constraints on the age of early Neoproterozoic carbonate successions in North China. Precambrian Res. 246, 208-225 (2014).

44. Summons, R. E., Franzmann, P. D. \& Nichols, P. D. Carbon isotopic fractionation associated with methylotrophic methanogenesis. Org. Geochem. 28, 465-475 (1998).

45. Planavsky, N. J. et al. Low mid-Proterozoic atmospheric oxygen levels and the delayed rise of animals. Science 346, 635-638 (2014).

46. Berner, R. A. Sedimentary pyrite formation. Am. J. Sci. 268, 1-23 (1970).

47. Canfield, D. E. et al. Ferruginous conditions dominated later Neoproterozoic deep-water chemistry. Science 321, 949-952 (2008).

48. Johnston, D. T., Wolfe-Simon, F., Pearson, A. \& Knoll, A. H. Anoxygenic photosynthesis modulated Proterozoic oxygen and sustained Earth's middle age. Proc. Natl Acad. Sci. 106, 16925-16929 (2009).

49. Shen, B., Wimpenny, J., Lee, C.-T. A., Tollstrup, D. \& Yin, Q.-Z. Magnesium isotope systematics of endoskarns: implications for wallrock reaction in magma chambers. Chem. Geol. 356, 209-214 (2013)

50. Galy, A. et al. Magnesium isotope heterogeneity of the isotopic standard SRM980 and new reference materials for magnesium-isotope-ratio measurements. J. Anal. At. Spectrom. 18, 1352-1356 (2003).

51. Opfergelt, S. et al. Mechanisms of magnesium isotope fractionation in volcanic soil weathering sequences, Guadeloupe. Earth Planet. Sci. Lett. 341-344, 176-185 (2012).

52. Huang, F., Zhang, Z., Lundstrom, C. C. \& Zhi, X. Iron and magnesium isotopic compositions of peridotite xenoliths from Eastern China. Geochim. Cosmochim. Acta 75, 3318-3334 (2011).

53. Pogge von Strandmann, P. A. E. et al. Variations of $\mathrm{Li}$ and $\mathrm{Mg}$ isotope ratios in bulk chondrites and mantle xenoliths. Geochim. Cosmochim. Acta 75, 5247-5268 (2011).

54. Teng, F.-Z. et al. Magnesium isotopic compositions of international geological reference materials. Geostandards and Geoanalytical Research 39, 329-339 (2015)

\section{Acknowledgements}

This study is supported by Natural Science Foundation of China (41272017 and 41322021 to B.S., and 41402025 to L.D.), State Key Laboratory of Palaeontology and Stratigraphy (133103 to L.D.) and U.S. National Science Foundation (EAR-1528553 to S.X.). We thank Linda Kah, Timothy Lyons and an anonymous reviewer for constructive comments on earlier versions of the manuscript.

\section{Author contributions}

B.S. and L.D. designed the project. B.S., X.L. and P.L. conducted field work. X.L. and Y.P. measured S isotopes. K.H. and S.K. measured Mg isotopes. L.D. and C.Z. measured C isotopes. B.S. performed modelling analyses. B.S., L.D. and S.X. led data interpretation and developed the manuscript. All authors contributed to discussion and manuscript revision.

\section{Additional information}

Supplementary Information accompanies this paper at http://www.nature.com/ naturecommunications

Competing financial interests: The authors declare no competing financial interests.

Reprints and permission information is available online at http://npg.nature.com/ reprintsandpermissions/

How to cite this article: Shen, B. et al. Molar tooth carbonates and benthic methane fluxes in Proterozoic oceans. Nat. Commun. 7:10317 doi: 10.1038/ncomms10317 (2016)

\section{(c) (i)}

This work is licensed under a Creative Commons Attribution 4.0 International License. The images or other third party material in this article are included in the article's Creative Commons license, unless indicated otherwise in the credit line; if the material is not included under the Creative Commons license, users will need to obtain permission from the license holder to reproduce the material. To view a copy of this license, visit http://creativecommons.org/licenses/by/4.0/ 